\title{
RECENZJA
}

\section{Przemysław Pluciński*}

\author{
O SOCJOLOGIE NIERACJONALNEGO DZIALANIA \\ Recenzja książki Marka Nowaka pt. Teoria nieracjonalnego działania. \\ Socjologiczne studium na temat wolontariatu i spolecznego aktywizmu, \\ Wydawnictwo Naukowe UAM, Poznań 2015
}

\begin{abstract}
Abstrakt. Celem niniejszego artykułu recenzyjnego jest „pozytywna krytyka” - tak jak pojmowali ją Max Weber, a za nim wielu socjologów, m.in. Stanisław Kozyr-Kowalski - głównych tez oraz pól problemowych zawartych w książce Marka Nowaka pt. Teoria nieracjonalnego działania. Główne z nich to: teza o przeracjonalizowaniu współczesnej socjologii, szczególnie socjologii działania, próby teoretycznej rekonceptualizacji działań „nieracjonalnych” w odwołaniu do idei voluntas, następnie zaś dyskusja wokół warunków strukturalnych dla działań aktywistycznych. Szczególnie istotny wydaje się w tym kontekście problem badań nad trzecim sektorem oraz ambiwalentny kontekst jego postępującej NGO-izacji. Wszystkie wskazane wątki zostały poddane krytycznej dyskusji.
\end{abstract}

Słowa kluczowe: socjologia teoretyczna, teoria działania społecznego, społeczeństwo obywatelskie, ruchy społeczne, aktywizm, voluntas, welfare state.

Proponowana tu perspektywa krytycznej lektury książki Marka Nowaka pt. Teoria nieracjonalnego działania $\mathrm{w}$ swoim zamyśle miała być bardziej zwięzła. Okazało się jednak, że sama materia książki, zawarte w niej zatem treści, jak również - paradoksalnie - poniechania i braki, sprowokowały konieczność dłuższej wypowiedzi, bliższej formule ,artykułu recenzyjnego". Jest ona przy tym przygotowana zgodnie ze standardami „pozytywnej krytyki” (Weber; Kozyr-Kowalski 1999) - dokonując krytycznej analizy pracy, stara się też wydobywać z niej przede wszystkim to, co intrygujące i wartościowe.

Książka Marka Nowaka pod względem formalnym ma dość przejrzystą strukturę: składają się na nią wprowadzenie poświęcone wyjaśnieniu pojęć oraz dwie części. Pierwsza z części nosi tytuł „Wnioskowanie oparte na teorii”, druga „Wnioskowanie oparte na analizach teoretycznych”. Mimo zamysłu autora, by książka tworzyła organiczną całość, pracę charakteryzuje swoiste pęknięcie.

* Dr, Zakład Socjologii Zróżnicowania Społecznego, Instytut Socjologii, Uniwersytet Adama Mickiewicza, ul. Szamarzewskiego 89, budynek C, 60-568 Poznań, e-mail: plucin@amu.edu.pl 
Integracja części teoretycznej z częścią empiryczną wydaje się momentami problematyczna. Nie tyle jednak ze względu na jakieś istotne błędy merytoryczne, co raczej z uwagi na multilinearność narracji. Analiza charakteryzuje się bowiem polifonią wątków, nie wszystkie z nich są poprowadzone konsekwentnie. Co więcej, gdyby zastosować na wstępie florystyczną metaforę i przyrównać tę książkę do zakwitającego drzewa, to okazuje się, że nie każda gałąź (teoretyczny i badawczy pomysł), która wyrasta z pnia, równie pięknie i w pełni rozkwita.

Osobną kwestią pozostaje sprawa bardzo hermetycznego i nie zawsze przejrzystego języka. Nie chodzi w tym przypadku jedynie o profesjolekt, raczej o wrażenie „,przesady żargonu”. Należy przy tym mieć nadzieję, że autor nie zostanie przez czytelników posądzony o „czarnoksięstwo” (Andreski 2002), albowiem lektura książki Nowaka, choć percepcyjnie trudna, identyfikuje bardzo istotne problemy socjologiczne. Jak zresztą przedstawił to sam autor, Teorię nieracjonalnego działania należy potraktować jako prowokację (wymierzoną w ,,przeracjonalizowanie" socjologii działania) i zaproszenie do dyskusji według zasad narracji socjologicznej. Jeśli zatem przyjąć zaproszenie autora, to dyskusję warto otworzyć tam, gdzie tropy się urywają. Prócz tego bowiem, co książka bezpośrednio oferuje, równie intrygujące są w niej problemy zidentyfikowane, ale nierozwiązane.

Omawiana praca Marka Nowaka ogniskuje w sobie przynajmniej kilka klasycznych, konstytutywnych dla socjologii pól problemowych, stroniąc przy tym od mód intelektualnych. W tym sensie jest pracą, w której autor podejmuje się próby połączenia dwóch paradygmatycznych, do dziś nie w pełni zadowalająco uzgadnialnych, sposobów patrzenia na społeczeństwo: ujęcia działaniowego i perspektywy systemowo-strukturalnej ${ }^{1}$. Jest to zatem, po pierwsze, praca o działaniu jako takim i jego strukturalnych uwarunkowaniach, po drugie zaś rozprawa z zakresu socjologii działania i aktywizmu, które to perspektywy zostają ostatecznie przez Marka Nowaka splecione. Wątek działaniowy jest przez autora rozwinięty w ramach krytyki zastanych koncepcji działaniowych i próby ich rekonceptualizacji, znajdując dopełnienie w analizach empirycznych; wątek drugi, strukturalno-systemowy, oparty jest przede wszystkim na analizie rozmaitych sposobów organizowania welfare state jako potencjalnego czynnika różnicującego społeczną aktywność. Całość uzupełniona jest szeregiem pojęć-korelatów oraz koncepcji, które zwykle towarzyszyły i towarzyszą przyjętej przez autora optyce. Są to zatem: kwestie społeczeństwa obywatelskiego, aktywizmu, działalności trzeciosektorowej, ruchów społecznych, motywów zaangażowania. Wyróżnione tu części składowe sugerować mogą, że próba, którą podejmuje Marek Nowak, nie jest łatwa. Wprawdzie, co oczywiste, nie podejmuje się on zadania budowania

${ }^{1}$ Punktami byłyby tu zatem propozycje teoretyczne Webera, Parsonsa, Habermasa czy późnego Giddensa, by wskazać te najbardziej oczywiste. Do części z nich zresztą Nowak nawiązuje, nie fundując jednak w żaden sposób na fundamencie „myślenia klasykami” kapliczki. 
teorii ogólnej społeczeństwa, a towarzyszy mu zamysł zdecydowanie skromniejszy, niemniej wątków splątanych w pracy jest wiele, zatem wysiłek podjęty celem ich „rozsupłania” musi być spory. Tym bardziej że kompleksowa analiza teoretyczna prowadzi do wnioskowania empirycznego, opartego na bogatych danych zastanych (zarówno międzynarodowych, o porównawczym charakterze, jak również ogólnopolskich) oraz danych pierwotnych wytworzonych w projekcie badawczym poświęconym działaniom woluntaryjnym.

Zasadnicze intencje Nowaka uzupełnia perspektywa ,multiparadygmatyczności”, którą podbudowuje on korzystając z koncepcji „,neoklasycyzmu socjologicznego". Co ciekawe, Nowak odwołuje się do jego dwóch postaci. Pierwsza z nich została opracowana i była rozwijana od lat 90 . XX wieku przez poznańskiego socjologa Stanisława Kozyra-Kowalskiego, jednak po wstępnej kodyfikacji koncepcji dalsze prace nad jej rozwojem przerwała jego przedwczesna śmierć. Drugie, o dekadę późniejsze, wezwanie do uprawiania „neoklasycznej socjologii” pochodzi już od Michaela Burawoya. Obie wersje „neoklasycyzmu”, mimo różnic, łączy jedno - silne, „ekumeniczne” przekonanie o jedności socjologii dzięki rozmaitości perspektyw w jej obrębie. Jądrem neoklasycyzmu, szczególnie w ujęciu Kozyra-Kowalskiego, jest hermeneutyczna praca nad klasycznymi pojęciami i ich teoretyczna obróbka mająca na celu przekształcenie „dawnych" pojęć w nowoczesne narzędzia pracy intelektualnej. Dokładnie w ten sposób, inspirowany Kozyrem-Kowalskim i Burawoyem, zgodnie z regułami „neoklasycznymi", Nowak pracuje z klasycznymi pojęciami ${ }^{2}$. Centralne z nich to pojęcie voluntas oraz kategoria praxis, w sensie, jaki przypisała im Hannah Arendt. Nowak stara się je zintegrować, jednak nie na poziomie genealogii pojęć, ale na poziomie zgodności semantycznej, poszukując „odpowiedniości sensowej”. Autor Teorii nieracjonalnego dziatania sięga po nie przynajmniej z dwóch powodów - po pierwsze interesuje go dyskusja z ,przeracjonalizowaniem” socjologii, po drugie - to w koncepcie voluntas, połączonym z Arendtiańskim pojmowaniem praxis, dopatruje się motywów, które, jego zdaniem, pozwalają wyjaśniać „nieracjonalność" nakierowanych na innych, realizowanych poza motywem ,nagich interesów”, działań jednostkowych. W domyśle zatem interesuje Nowaka autoteliczność wolontariatu.

Kategoria voluntas zostaje przez Nowaka połączona z ideą praxis. Ten jednak moment pracy teoretycznej budzi kilka wątpliwości. Po pierwsze, autor

\footnotetext{
${ }^{2}$ Nie jest to ujęcie we współczesnej socjologii częste, nie jest dominujące. Między innymi dlatego zapewne, że nowoczesne rygory wydajności pracy naukowej i neoliberalizacji akademii, w zgodzie z nimi zaś trajektoria współczesnych prac i kariery naukowej, sprzyjają nie tyle rzetelnym studiom nad myślą klasyków i otwartym do nich odwołaniom, co raczej fabrykacją coraz to nowych pojęć i kreacją mód intelektualnych, ewentualnie umiejętnością szybkiego przełączania się pomiędzy rozmaitymi trendami. W tym sensie, z perspektywy „neokolumbizmu socjologicznego" (Kozyr-Kowalski 1999), perspektywa Nowaka jawić się może jako „tradycjonalistyczna” czy „zachowawcza”.
} 
wprowadza kluczowy dla filozofii Arendt kontekst, jak to określa, „ujawniania” (appearance) tożsamości przed innymi. Okazuje się jednak, że mamy już w Polsce do czynienia z alternatywną translacją tego samego pojęcia - „przestrzeni pojawiania się" (Moskalewicz 2011). Nowak nie podejmuje dyskusji z zastanym kontekstem translacyjnym, co - zważywszy na to, że dokonuje drobiazgowej analizy pojęciowej - wzbudza wątpliwości. Tym bardziej że dla Arendt bardzo ważne było „uprzestrzennienie” koncepcji „,pojawiania”/,ujawniania się” (space of appearance), nawet jeśli to ostatnie ma przede wszystkim społeczny sens. Odnoszę wrażenie, że przestrzenność tę Nowak ruguje z kontekstu analitycznego. Po drugie, co chyba bardziej istotne, poza wątkiem Arendtiańskim autor podejmuje bardzo szeroko zakrojoną dyskusję z zastanymi koncepcjami działania (Durkheim, Weber, Habermas). Dyskusja ta jednak wydaje się zbyt szeroka, przynajmniej z uwagi na celowość projektu, jaki zarysowuje Nowak. Wpisuje się raczej w określone formuły „rytualizmu akademickiego" w polu „wytwarzania tekstów” i z tej perspektywy wydaje się raczej być asekuracją przed potencjalnymi zarzutami o brak dyskusji z klasykami, niż wynikać z logiki wywodu, a może nawet głębokiego wewnętrznego przekonania autora o konieczności przywoływanego zabiegu. Po trzecie wreszcie, brakuje w pracy wątków, które - w polu analitycznym, w którym pracuje autor - zdają się być niejako samonarzucające; chodzi o szerszą dyskusję wokół intersubiektywności. Co więcej, perspektywa praxis-voluntas na poziomie konstrukcyjnym bardzo mocno koresponduje z klasycznymi, rudymentarnymi w zasadzie tezami interakcjonizmu symbolicznego. Wszak autor pisze:

[...] „różnienie się” jest związane z ujawnianiem (wobec innych), nabierającym sensu w społecznym kontekście, który można określić kontekstem symbolizowania działania. Interpretacja socjologiczna dookreśla, że ujawnianie to stwarza (lub raczej może stwarzać) przestrzeń „pomiędzy” [...]. Od chwili „wybrzmienia” (zakończenia) działania uruchamia się zbiorowy proces społecznej interpretacji. (Nowak 2015)

Prócz zrekonstruowanego powyżej aspektu teoretycznego, książka Nowaka wpisuje się w wieloletnie zainteresowania autora społeczeństwem obywatelskim oraz sposobami jego poznania (Nowak, Now osielski 2008). W trakcie tej drogi badawczej Nowak (niekiedy ze współpracownikami) postawił kilka interesujących tez, między innymi tę o „społecznym bezruchu” (Nowak, Nowosielski 2006). Druga, nieco mniej obszerna i empiryczna część książki wydaje się być właśnie próbą domknięcia określonego etapu zainteresowań naukowych autora. Preludium stanowi, co znajdziemy już zresztą we wstępie do książki, Marshallowskie ujęcie obywatelstwa i próba - znów w formule neoklasycznej - jego rozwinięcia. Nowak proponuje zatem formę „transgresyjnych form obywatelstwa”, przez co rozumie ich późno-nowoczesną postać. Przywołuje zatem szeroką gamę działań obywatelskich: walk o uznanie i tożsamość (na przykład etniczną, ale i seksualną), roszczeń do nowej polityzacji życia, walk socjalnych w kontekście rosnących nierówności oraz problemów związanych z prekaryzacją, nowych 
ruchów ekologicznych (na przykład tych walczących z globalnym ociepleniem), nowych trybalizmów, ruchów społecznych związanych ze zwrotem przestrzennym czy silnych ruchów powstających ad hoc (na przykład ruchów przeciwko „cenzurze Internetu” i zaostrzaniu kontroli własności intelektualnej). Plan zarysowany jest dość szeroko - okazuje się jednak, że w kontekście rozwoju narracji jest on raczej swobodnie potraktowaną ramą, być może nawet metaforą hybrydyzacji pola społecznego aktywizmu, niż konkretnym planem badawczym.

Ostatecznie bowiem Nowak skupia się, przywołując wątki empiryczne, na badaniu aktywizmu w sposób dość formalny, za pomocą tradycyjnych empirycznych badań ilościowych. Ich siła tkwi w możliwościach analiz porównawczych. To jedna z największych, moim zdaniem, zalet książki. Analizy porównawcze Nowaka starają się zweryfikować hipotezę o trzech głównych przyczynach aktywizmu i jego uwarunkowaniach za pomocą trzech wymienionych czynników: 1) inspirowanego religijnie ,genetycznego" modelu wspólnoty (paralele przecież post-Weberowskie) ${ }^{3} ; 2$ ) aspektu świadomościowego - czyli poglądów na temat aktywności, relatywnie łatwych w pomiarze socjologicznym za pomocą standardowych metod oraz 3) typu polityki państwa i poziomu życia.

Kluczowym wątkiem książki wydaje się być ów trzeci, ostatni - autor poświęca mu najwięcej miejsca. Próbuje mianowicie szukać związków między typem państwa, dokładniej zaś jego sposobami zaangażowania w kwestie socjalne oraz integracji polityki społecznej we względnie spójny system, z optyką i narzędziami polityki gospodarczej, a poziomem zaangażowania. Orzeka zatem, że modele społeczno-gospodarcze oparte na welfare economics i instytucji welfare state cechują się wyższym poziomem społecznego zaangażowania niż te, w których welfare jest na rudymentarnym poziomie. Nie chodzi tu jednak oczywiście jedynie o poziom potencjalnych transferów, ale przede wszystkim o zinstytucjonalizowaną aksjologię (jej wskaźnikami mogą być komodyfikacja i dekomodyfikacja) czy nawet określoną ontologię społeczną - wszak oparcie się na idei welfare to w pewnej mierze optowanie za myśleniem kolektywnym, wbrew doktrynerskim przekonaniom, że „nie ma czegoś takiego jak społeczeństwo”.

Wróćmy jeszcze na chwilę do kontekstu welfare. Nowak wskazuje, że „prosta modernizacja poprzez urynkowienie” sprzyja „społecznemu bezruchowi”. W tym to sensie autor idzie pod prąd polskiej socjologii ostatniego ćwierćwiecza, która dość mocno wpisywała się i legitymizowała określoną, opartą przede wszystkim na silnej komodyfikacji, opcję modernizacji, swoistą mimetyczną

${ }^{3}$ Interesujące są te wątki, bezpośrednio Weberowskie, które są powiązane z kontekstem religijnym oraz sacrum. Analiza tak pojmowanych źródeł woluntaryzmu nie jest częsta we współczesnych „socjologiach działania” i aktywizmu czy analizach ruchów społecznych. W ostatnim czasie w swojej analizie Rewolucji 1905 roku zwracał na to uwagę Wiktor Marzec (2016), który omawiając relatywnie szeroko repertuary robotniczej kontestacji, wskazywał na problem rekonstrukcji określonych, mających swoje religijne źródła, praktyk społecznych (na przykład procesje), ich rekontekstualizację oraz przeobrażenie w praktyki protestu. 
transformację. Symbolem uwikłania socjologii w tak pojmowany normatywizm mogą być chyba słowa Henryka Domańskiego, kiedy pisał: „Naszym celem jest Zachód!" (Domański 2002: 8). Nie dowiadujemy się jednak jednego: na ile teza ta jest - choćby względnie - uniwersalna, na ile zaś ma charakter ,idiograficzny” i dotyczy konkretnego społeczno-historycznego doświadczenia, ograniczyć ją zatem należałoby do konkretności polskiego i, nieco szerzej, środkowoeuropejskiego doświadczenia transformacji. Być może jednak za wcześnie na takie wnioski.

Autor w kontekście analizy porównawczej wprowadza też obiecujące pojęcie - „naturalnej stopy aktywizmu”. Jest to oczywiście nawiązanie do „hipotezy naturalnego poziomu” określonych zjawisk społecznych, przede wszystkim ,naturalnej stopy bezrobocia", sformułowanej przez liberalnego ekonomistę, twórcę monetaryzmu, Miltona Friedmana ${ }^{4}$. Pojęcie „naturalnego poziomu aktywizmu” jest jednak tak intrygujące i obiecujące, jak i problematyczne. Autor poświęca w tym przypadku więcej miejsca rekonstrukcji perspektywy Friedmanowskiej niż próbie jej neoklasycznej rekonceptualizacji. Nowak nie mierzy się też z problematycznością pojęcia. O ile sama koncepcja „naturalnej stopy bezrobocia”, zakładając implicite dominację stosunków kapitalistycznych, zatem i przekonanie - którego wektor skierowany jest przecież przeciwko w zasadzie drobnomieszczańskim mitom „kapitalizmu drobnych właścicieli” - że większość populacji „skazana” jest na pracę najemną jako życiową konieczność, o tyle w przypadku „naturalnej stopy aktywizmu", o ile dobrze odczytuję intencje Marka Nowaka, zakładać musielibyśmy z kolei w pewnej mierze „obligatoryjny” charakter społecznego aktywizmu. To zaś wymagałoby określonej, bardzo normatywnej wizji społeczeństwa, w ramach której to zaangażowanie jest pożądaną normą, zaś désintéressement jej „pogwałceniem”. Co do takiej wizji ładu społecznego nie ma jednak zgody i nawet jeśli jest możliwa - i przez wielu, tak aktywistów, jak i socjologów, pożądana - to jednak zawsze związana jest z określonym usytuowaniem. Być może jednak właśnie w tę stronę skierowany i pogłębiony, choćby w duchu Eliasowskim, namysł pozwoliłby autorowi na dopracowanie frapującej idei „naturalnej stopy aktywizmu". Reasumując, jeśli Nowak poprowadziłby dalsze prace nad tak zamierzoną próbą dopracowania prezentowanej koncepcji, mogłoby to dać bardzo interesujące efekty poznawcze i badawcze.

Jeśli zatem traktować książkę Nowaka - zgodnie z intencjami jej autora - jako próbę konfrontacji z „przeracjonalizowaniem” socjologii, przede wszystkim zaś $\mathrm{z}$ uwikłaniem socjologii w normatywizm modernizacji, sprowadzany do monoidei modernizacji przez rynek, to jest ona dobrym asumptem i zachętą do nowych dyskusji na temat (niespełnionych?) obietnic modernizacyjnych, społeczeństwa

${ }^{4}$ Ruch Nowaka jest ciekawym przykładem ,przechwytywania pojęć”. Autor wydobywa bowiem pojęcie z normatywnego kontekstu monetarystycznej ekonomii Friedmana i rekonstytuuje idee „naturalnego poziomu”, by móc wykorzystywać ją do badań w zupełnie innym kontekście, bardzo odległym od Friedmana, badań nad welfare i jego społecznymi konsekwencjami, na przykład dla poziomu aktywizmu. 
obywatelskiego, aktywizmu, wreszcie relacji między tzw. trzecim a czwartym sektorem. Moje uwagi wieńczące krytyczne omówienie pracy Nowaka skupią się właśnie na zagadnieniach obywatelskiego aktywizmu, tym bardziej że sam autor przez wiele lat pracował nad tymi zagadnieniami.

Nieco zaskakuje w tym aspekcie, szczególnie zważywszy na wcześniejsze prace autora, bardzo inkluzywne, możliwie najszersze - tak jak definiują to ilościowe badania, z których autor z zaskakująco małym krytycyzmem korzysta - rozumienie aktywności obywatelskiej. Ten sam status na potrzeby analizy ma bowiem aktywność w partiach politycznych, stowarzyszeniach i inicjatywach nieformalnych. Co więcej, Nowak zdaje się akceptować zatarcie granicy między „trzecim” a „czwartym” sektorem, co - moim zdaniem - jest jednym z istotniejszych przeoczeń książki. Nawet gdybyśmy zastosowali tu najprostszą ramę, zrównującą społeczeństwo obywatelskie z działalnością bardzo zróżnicowanych wewnętrznie i między sobą NGO's, rodzi to jednak problemy, które na kartach książki bywają zasygnalizowane, ale w sposób nazbyt zdawkowy. Liczne ryzyka NGO-izacji, a nawet QUANGO-izacji już od lat są bowiem przedmiotem krytycznych analiz badaczy zainteresowanych społeczeństwem obywatelskim, aktywizmem czy ruchami społecznymi, wraz z postulatami wyjścia ,poza NGO-izację” (Jacobs son, Sax onberg 2013). Nie oznacza to przy tym, że zagadnienia związane z aktywizacją i stymulacją rozwoju społeczeństwa obywatelskiego tracą na znaczeniu. Sam rozkwit trzeciego sektora jednak, zgodnie z „dialektyką życia społecznego”, może prowadzić do nieprzewidzianych kryzysów. Sama idea ,społeczeństwa obywatelskiego" może być przy tym przechwycona i instrumentalnie wykorzystywana - nie dla obrony tego, co publiczne, ale dla wzmacniania procesów komodyfikacji. Innymi słowy, wzrost aktywności społecznej, przyrost trzeciego sektora może być instrumentalizowany i służyć ,nieprzyjaciołom społeczeństwa otwartego”. W zdecydowany sposób tę kwestię postawił ostatnio Paweł Załęski:

Powszechnie podzielana teza o pozytywnym wpływie trzeciego sektora na społeczeństwo jest nie do obronienia na gruncie empirycznym. Proste statystyki pokazują, że jest dokładnie odwrotnie, niż się powszechnie sądzi: im więcej jest organizacji pozarządowych, tym więcej osób spędza część życia w więzieniach, tym więcej osób żyje poniżej granicy ubóstwa, tym niższy jest udział w PKB wydatków państwa na szkolnictwo i służbę zdrowia, a nawet tym niższy staje się kapitał społeczny (sic!). I nie są to statystyki charakterystyczne tylko dla Polski, ale także dla wielu innych państw z grona zwanego demokratycznym, ze Stanami Zjednoczonymi na czele. (Załęski 2016)

W innym miejscu Załęski diagnozuje równie mocno:

Organizacje pozarządowe przyczyniają się do depolityzacji społeczeństwa. Służy temu ich sposób funkcjonowania, oparty na publicznych grantach i dotacjach. Stanowi on mechanizm instytucjonalizacji ruchów politycznych (zwanych w konsekwencji „społecznymi”) w organizacje usługowe, zajmujące się łataniem dziur po niedofinansowanych instytucjach państwa opiekuńczego. (Załęski 2016) 
Co ciekawe, również autor omawianej książki stawiał swego czasu podobną do krytyki Załęskiego tezę o „pracy woluntaryjnej” jako „systemowym plastrze” (Nowak 2012), uprawdopodobniając hipotezę jej immunizującej system funkcji. Nie wybrzmiewa ona jednak w książce niemal w ogóle.

Pozwolę sobie w zakończeniu na swoiste „rondo”, czyli powrót do wątków już w recenzji obecnych. Nowak, odwołując się do wyników badań empirycznych, zakłada, że aktywności obywatelskiej sprzyja dekomodyfikacja i oparcie się na aktywnym państwie. Kluczowa jest zatem próba stymulacji rozwoju trzeciego sektora i zachęta do działań opartych na voluntas. W tym też sensie pobrzmiewa $\mathrm{u}$ autora swoista tęsknota za logiką welfare state, aktywnym państwem stymulującym obywatelstwo. Znów jednak nie wiemy jednego - czy owa tęsknota nie jest tęsknotą za normatywnym wzorem bezpowrotnie minionym, wzorem instytucjonalnym, który nigdy nie zdołał się „zagnieździć” w Polsce i innych krajach o postsocjalistycznym rodowodzie (Jacobsson 2016: 11).

Książka Nowaka jest mozaikowa, pełna splątanych wątków. Z drugiej jednak strony opiera się na dość klarownej „wyobraźni socjologicznej”, której główny interes moglibyśmy wyrazić przywołując Foucaulta: „Trzeba bronić społeczeństwa!". Ta niełatwa w lekturze praca na pewno spełnia przynajmniej jedną obietnicę - jest prowokująca - i na tym polega jej siła.

\section{Bibliografia}

Andreski S. (2002). Czarnoksięstwo w naukach spotecznych. Oficyna Naukowa, Warszawa.

Buraw oy M. (2001). Neoclassical Sociology: From the End of Communism to the End of Classes, "American Journal of Sociology", vol. 6, no. 4 (January), s. 1099-1120.

Domański H. (2002). Polska klasa średnia. Fundacja na Rzecz Nauki Polskiej, Wrocław.

Jacobsson K. (ed.) (2016). Urban grassroots movement in Central and Eastern Europe. Routledge, London, New York.

Jacobsson K., Saxonberg J. (eds.) (2013). The Development of Social Movements in Central and Eastern Europe. Ashgate, Farnham, Surrey.

Kozyr-Kowalski S. (1999). Socjologia, społeczeństwo obywatelskie i państwo. Wydawnictwo Naukowe Uniwersytetu im. Adama Mickiewicza, Poznań.

Marzec W. (2016). Rebelia i reakcja. Rewolucja 1905 roku i plebejskie doświadczenie polityczne. Wydawnictwo Uniwersytetu Łódzkiego, Łódź, Towarzystwo Autorów i Wydawców Prac Naukowych UNIVERSITAS, Kraków.

Moskalewicz M. (2011). Przestrzenie pojawiania się. Miejsce lokalności w myśli Hannah Arendt, [w:] M. Nowak, P. Pluciński (red.), O miejskiej sferze publicznej. Obywatelskość i konflikty o przestrzeń. ha! art., Kraków.

Nowak M. (2012). The System's Sticking Plaster. Voluntary Work in Late Modernity, „Studia Historiae Oeconomicae", vol. 30, s. 129-152.

Nowak M. (2015). Teoria nieracjonalnego działania. Socjologiczne studium na temat wolontariatu i społecznego aktywizmu. Wydawnictwo Naukowe Uniwersytetu Adama Mickiewicza, Poznań.

Nowak M., Now osielski M. (red.) (2006). Czy społeczny bezruch? O społeczeństwie obywatelskim i aktywności we współczesnej Polsce. Instytut Zachodni, Poznań. 
Nowak M., Now osielski M. (red.) (2008). Jak badać spoleczeństwo obywatelskie? Doświadczenia praktyków. Wydawnictwo Naukowe Uniwersytetu Adama Mickiewicza, Poznań.

Załęski P. S. (2016). NGO-izacja społeczeństwa politycznego i segregacja ekonomiczna, „Nowy Obywatel”, http://nowyobywatel.pl/2016/10/19/ngo-izacja-spoleczenstwa-politycznego-isegregacja-ekonomiczna/ [dostęp 07.03.2017].

\title{
Przemysław Pluciński
}

\section{TOWARDS THE SOCIOLOGY OF NON-RATIONAL ACTION BOOK REVIEW: MAREK NOWAK, TEORIA NIERACJONALNEGO DZIALANIA. SOCJOLOGICZNE STUDIUM NA TEMAT WOLONTARIATU I SPOLECZNEGO AKTYWIZMU, WYDAWNICTWO NAUKOWE UAM, POZNAŃ 2015}

\begin{abstract}
The review article offers a "positive critique" - as it was understood by Max Weber and his followers, like Polish sociologist Stanisław Kozyr-Kowalski among others - of main theses and problems contained in Marek Nowak's latest book Nonrational Theory of Action. The attention is focused on: the thesis of over-rationalized character of modern sociology, especially the sociology of action, attempts to reconceptualization of "non-rational" actions in close reference to the idea of voluntas, the discussion on structural conditions for activist actions, the third sector problems and the process of NGO-ization and its ambivalence. The paper examines these most crucial problems of Nowak's perspective.
\end{abstract}

Key words: theoretical sociology, theory of social action, civil society, social movements, activism, voluntas, welfare state. 